\title{
Os planos para o Império e a história da geografia no Brasil
}

\author{
The plans for the Empire \\ and the history of geography in Brazil \\ Gustavo Soares Iorio
}

Planos para o Império: os planos de viação do Segundo Reinado (1869-1889)

Manoel Fernandes de Souza Neto

São Paulo: Alameda, 2012.

A história da geografia no Brasil é ainda uma temática que não dispõe de vasta bibliografia, mas esse quadro vem mudando. Um verdadeiro campo de estudos está em formação. Artigos, teses e livros têm surgido estabelecendo um diálogo mais próximo com a historiografia, trazendo debates teórico-metodológicos, levantando questões pertinentes à compreensão não só da geografia disci-

Gustavo Soares Iorio é doutorando do Programa de Pós Graduação em Geografia da Universidade Federal do Rio de Janeiro (UFRJ) e bolsista do CNPq (gustavosoaresiorio@yahoo.com.br).

Resenha recebida em 17 de agosto de 2012 e aprovada para publicação em 11 de março de 2013.

Est. Hist., Rio de Faneiro, vol. 26, no 51, p. 243-246, janeiro-junho de 2013. 


\section{Gustavo Soares Iorio}

plinar, mas de todo um universo de representações e práticas sociais. Esse avanço é muito positivo para a geografia e para as ciências sociais como um todo, na medida em que a abordagem se volta para a construção e os usos históricos de conceitos e categorias; as formas de consagração das maneiras de ver e classificar o mundo, de qualificar lugares, identificar regiões, ordenar territórios.

O trabalho de Manoel Fernandes, originalmente tese de doutorado apresentada ao Programa de Pós-Graduação em Geografia da Universidade de São Paulo, é certamente uma das melhores expressões desse processo. Sua obra aborda os planos de viação elaborados no Segundo Reinado, entre os últimos anos da Guerra do Paraguai e a Proclamação da Republica (1869-1889). O autor analisa os planos de viação como interpretações sobre o território, ou melhor, interpretações sobre o território diante dos projetos de nação. Em suas palavras:

Diante desse quadro o que se nos colocou foi: como as elites liam o território a partir dos planos de viação? Como viam a nação a construir, já que propunham banhar os bárbaros do sertão com as águas civilizadoras do Atlântico? Quais problemas identificavam como sendo os mais urgentes do ponto de vista estratégico, comercial ou político para o Estado? Quais as dissensões políticas entre os engenheiros passíveis de serem percebidas nas soluções técnicas apresentadas por eles? Como o discurso técnico em torno das vias de comunicação a construir ganha importância política nas últimas duas décadas do Segundo Reinado? (p. 26)

Num contexto de fé no "progresso" e na "civilização", expansão mundial do capitalismo em seu estágio imperialista e modernização através de Estados nacionais soberanos e territorialmente delimitados, o Brasil vivia a contradição entre suas heranças coloniais e o imperativo moderno. $O$ ímpeto de se modernizar esbarrava em instituições arraigadas como a monarquia e o escravismo, em problemas estruturais como a dispersão territorial, a debilidade das vias de circulação e o arcaísmo evidenciado com a Guerra do Paraguai. Fazia-se necessário modernizar o Estado e para isso era preciso modernizar o território. É nesse contexto que surgem os planos viários.

Os autores desses planos são os sujeitos sociais da análise. Manoel Fernandes analisa esses sujeitos por três esferas que ele distingue em termos metodológicos (mas que se confundem na vivência objetiva): personagens, instituições e saberes. Ele trafega pela biografia de seus sujeitos, ${ }^{1}$ identifica os percursos

1. Os autores analisados, com as respectivas datas de seus planos, são: Eduardo José de Moraes (1869), João Ramos de Queiroz (1874), André Rebouças (1874), Honório Bicalho (1882)e Antônio Bulhões (1882). Foram esses os engenheiros que, no período recortado, publicaram planos que abrangiam todo o território nacional. 
de formação e os exercícios da profissão para caracterizá-los. Todos são homens, engenheiros, estudados em escolas militares (Academia Imperial Militar) e de engenharia civil (Escola Central, que depois veio a ser Escola Politécnica), na maioria das vezes com passagens pela Europa. Todos frequentavam lugares em comum, participavam de associações como a Sociedade Auxiliadora da Indústria (SAIN), o Instituto Politécnico e o Clube de Engenharia. Nesses meios de convivência teciam uma forte rede de socialização, e mesmo um espírito corporativo de uma profissão em ascensão. Projetavam-se como detentores de um saber técnico muito bem delimitado pela fronteira da matemática. Esse era o saber moderno, legitimamente capaz de planejar um sistema de transportes dinâmico, apto a integrar o território nacional para fins militares, políticos e comerciais.

Manoel Fernandes observa com astúcia a inserção social desses engenheiros. Bastante ativos por meio das associações e de seus trabalhos, eles se acomodavam - com algumas tensões - como arautos do progresso no seio da sociedade oligarca, bacharelesca, agrário-exportadora, escravocrata e monarquista no Brasil do Segundo Reinado (o Ministério de Agricultura, Comércio e Obras Públicas era o maior contratante desses profissionais). Este é o ponto forte do livro: a composição de uma trama de sujeitos organizados em uma verdadeira corporação profissional que se põem como portadores de uma "novidade" (o saber técnico, moderno) e únicos na capacidade de concretizá-las. Oriundos das classes médias, misturados entre as elites tradicionais através das associações e atuações profissionais, os engenheiros difundiam as ideias progressistas da modernização, vindas fundamentalmente da Europa, e assumiam para si a competência técnica para conduzi-la. A engenharia se projetava como um saber necessário, e os engenheiros enquanto a personificação das "soluções técnicas".

Os planos de viação são uma dessas soluções, e também a materialização das ideias e dos ideais que os autores portam no contexto discursivo no qual estão inseridos. Neles as divergências técnicas revelam dissensões políticas, como a opção por qual modal de transporte (ferroviário ou aquaviário) ou tamanho da bitola, no caso das ferrovias. De caráter estritamente técnico à primeira vista, esses debates remetem ao problema de como lidar com os fundos territoriais. Todas as soluções propostas nos cinco planos descritos convergem para a perspectiva de modernização territorial/estatal através de vias de comunicação a proporcionar uma efetiva ocupação do território em pequenas propriedades por colonos imigrantes ou escravos libertos. Como essas ideias contrariavam os interesses da oligarquia instalada, esses planos nunca foram postos em prática, o que de maneira alguma os deslegitima enquanto documentos do debate de um tempo histórico.

Manoel Fernandes se vale de uma base de documentos rica. Além dos cinco planos analisados diretamente, recorre a outros planos para regióes especí- 
ficas, relatórios do Ministério de Agricultura, Comércio e Obras Públicas, revistas e periódicos de instituições como a SAIN, o Instituto Politécnico, o Clube de Engenharia e o Instituto Histórico e Geográfico Brasileiro (IHGB). São dignos de nota os mapas anexados ao livro, tanto os que ilustram os planos quanto outros encontrados no acervo do Arquivo Nacional.

Em suma, neste livro Manoel Fernandes de Souza Neto dá visibilidade a aspectos importantes da sociabilidade nos derradeiros anos do Brasil Império. Particularmente para os geógrafos - sobretudo aqueles envolvidos com o tema da história da geografia - há aqui um significativo avanço qualitativo em termos teórico-metodológicos. Efetivamente, o ponto central é o entendimento que ele nos traz de uma historiografia das ideias sobre o território, com suas respectivas inserções e significados políticos, identificando-as a sujeitos sociais concretos. Certamente uma boa leitura. 